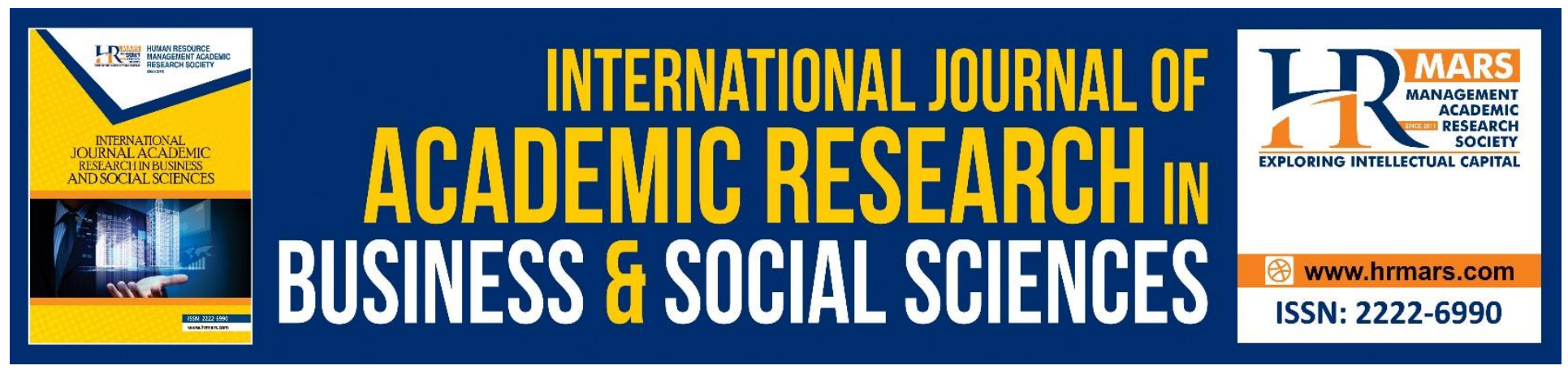

\title{
Need Analysis: Competency Development Measurement Instrument in Mastering the Content of Design and Technology Subject in High School
}

\author{
Owi Kim Huei, Ridzwan Che' Rus, Arasinah Kamis
}

To Link this Article: http://dx.doi.org/10.6007/IJARBSS/v9-i6/6065

DOI: $10.6007 /$ IJARBSS/v9-i6/6065

Received: 11 April 2019, Revised: 10 May 2019, Accepted: 09 June 2019

Published Online: 29 June 2019

In-Text Citation: (Huei, Rus, \& Kamis, 2019)

To Cite this Article: Huei, O. K., Rus, R. C., \& Kamis, A. (2019). Need Analysis: Competency Development Measurement Instrument in Mastering the Content of Design and Technology Subject in High School. International Journal of Academic Research in Business and Social Sciences, 9(6), 1043-1052.

\section{Copyright: (C) 2019 The Author(s)}

Published by Human Resource Management Academic Research Society (www.hrmars.com)

This article is published under the Creative Commons Attribution (CC BY 4.0) license. Anyone may reproduce, distribute, translate and create derivative works of this article (for both commercial and non-commercial purposes), subject to full attribution to the original publication and authors. The full terms of this license may be seen

at: http://creativecommons.org/licences/by/4.0/legalcode

Vol. 9, No. 6, 2019, Pg. $1043-1052$

http://hrmars.com/index.php/pages/detail/IJARBSS

JOURNAL HOMEPAGE

Full Terms \& Conditions of access and use can be found at http://hrmars.com/index.php/pages/detail/publication-ethics 


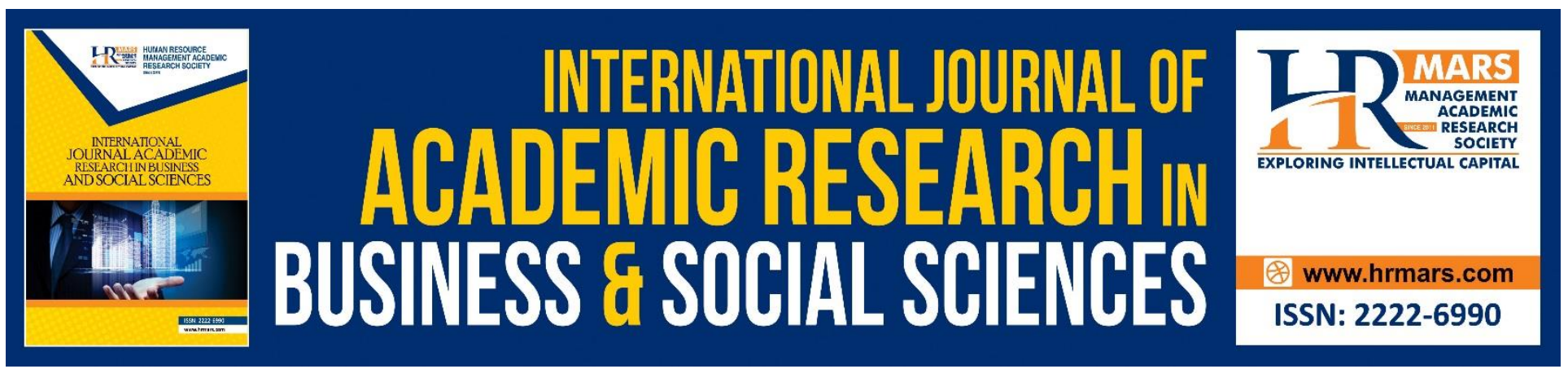

\title{
Need Analysis: Competency Development Measurement Instrument in Mastering the Content of Design and Technology Subject in High School
}

\author{
Owi Kim Huei, Ridzwan Che' Rus, Arasinah Kamis \\ Universiti Pendidikan Sultan Idris, Tg Malim Perak, Malaysia
}

\begin{abstract}
This paper intended to discuss the requirement analysis regarding the implementation of Design and Technology (D\&T) subject in which had been introduced back in 2017 for all Malaysian high school. D\&T is a performance-based subject, which includes the implementation of teaching and learning as well as assessment based on the standards of achievement. Therefore, the focus of this paper is to delve deeper into the challenges that came with the implementation of D\&T subject and the needs for the development of measuring instruments in which includes the mastering of content knowledge, skill mastery, and the ability to grasp the values in D\&T subject. This study is a research of quantitative methods and data collected through surveys. Questionnaire was used as the main instrument in this study. The finding among 100 respondents shows that $90 \%$ of respondents expressed the biggest challenge that they have to face is the lack of experience and teaching a nonoption subject, low in knowledge and skill in this case to teach D\&T subject. Finding show the level of content mastery among teachers is at a low level. In the meantime, $83 \%$ of the respondents agreed to the need to establish a competence measurement instrument that can measure the proficiency level of D\&T content knowledge among teachers. The researcher hoped that with this paper, it will help to broaden the perspective and understanding concerning various challenges that are associated with the implementation process of D\&T subject in secondary school. This study also discussed suggestions for future studies in teaching design and technology and It's suitable to problem solving in D\&T.
\end{abstract}

Keywords: Need Analysis, Design and Technology, Challenges

\section{Introduction}

Education is the basis for the success of a society. Hence, it is important to produce students that are equipped with thinking skill as what has been stated in the Malaysia Education Blueprint 2013-2025, which then led to the decision of introducing Design and Technology (D\&T) subject. D\&T is a subject, which based on the student abilities to apply the knowledge, skills, and values through activities such as designing and producing a product. Design and Technology subject taught to the student is about 
INTERNATIONAL JOURNAL OF ACADEMIC RESEARCH IN BUSINESS AND SOCIAL SCIENCES Vol. 9, No. 6, June, 2019, E-ISSN: 2222-6990 @ 2019 HRMARS

design criteria using technology in the process of construction and manufacturing products, while at the same time teach them to become individuals with global thinking as well as enhancing their comprehension concerning the latest technology, which can help them to be a capable person to solve problems in the future.

D\&T subject gives students the opportunity to combine or integrate both design and technology skills in one sphere by thinking creatively to produce products that meet human needs. The student will develop a range of skills that are in line with the needs of this modern industry. In this century, D\&T played a very challenging role due to the rapid development of information technology. Education has become a very crucial domain in which everyone will have the opportunity to learn about how to use current technology and at the same time be aware of the impact caused by the constant changes and development in technology. They think creatively by taking part in the efforts to improve the quality of life and help to solve the problems, and they are not only acting as technology users that are equipped with the knowledge, skills, and values, but they are also the creator of new products and the people who trigger new ideas.

A research to construct an instrument that can meet the criteria for teachers test needs to be conducted. Thus, this study aims to i. identify the challenges faced by teachers who teach Design and Technology subject in Malaysian high school, ii. identifying the level of content mastery among the teachers who teach Design and Technology subject in high school, and iii. to observe the needs for the development of a measurement instrument to measure the content mastery among teachers who teach the subject in high school. In order to answer these objectives, the researcher opted to use design and development research. In the study of this measurement instrument development, requirements analysis is part of the design and development of the instruments. According to Richey and Klein (2007), the strength of the design and development of instruments is that the study can be used to solve problems in a more specific context. The analysis phase is the initial phase of the study where necessary information related to the specific context and environment was collected for further analysis (Siraj, Alias, DeWitt, \& Hussin, 2013). Thus, before the measuring instruments were developed, the requirements analysis was conducted beforehand in order to determine the probability for problems to arise. The purpose of the analysis phase is to identify the probability for problems to occur (Branch, 2009; Gagne, Wager, Golas, \& Keller, 2005) and do what it takes to solve the problem (Reinbold, 2013).

The requirements analysis phase provides important information in determining the instructional materials for the design and development in the next phase (Gagne et al., 2005). In the context of this study, a requirement analysis was conducted the beginning of the measurement instruments development study in order to figure out what aspects were appropriate to be measured among teachers so that the content mastery of Design and Technology (D\&T) subject becomes more meaningful. As to fulfill the purpose, this study was conducted to identify the problems or obstacles faced by teachers when implementing D\&T subject in secondary school. And to meet this goal, there are several aspects of the target group that has been identified in which to ensure that the constructed instruments can be used. Rashidah (2013) stated that the analysis phase is the first phase of the study, which aimed to identify some aspects that are related to the target group. Target groups can provide useful information that can be used to develop instruments that meet the users' 
requirement. During the process of design and development of the instruments, the findings of the requirement analysis are assessed and used to develop constructs in measurement instruments.

In this study, the requirement analysis was conducted once the problems were identified and all information on the details and specification of existing instruments was obtained. As mentioned by Richey and Klein (2007), requirement analysis is conducted to determine product specifications. Hence, requirement analysis is important in determining how well the products for the teachers are produced so that existing problems can be solved with the purpose of achieving more effective content mastery. The findings and suggestions obtained in the analysis phase are then used in the design and development phase (DeWitt, 2010). The analysis phase provides important information that can be applied in the subsequent module of the design and development phase (Gagne et al., 2005). Information obtained from the requirement analysis is used to determine the constructs optimally and the sub-constructs in details.

\section{Methodology}

The researcher opted to carry out quantitative research in which the data is collected through the survey. A set of questionnaires was used as the main instrument in this study to obtain information and details regarding more complex issues. Research population involved in this study consists of 6422 teaching staff or teachers from a total of 1539 secondary schools throughout Peninsular Malaysia, which the required data were obtained from the Ministry of Education (2018). The data for the population involved in the research is as shown in the table below. Sampling techniques were conducted by purposely selecting respondents from homogeneous groups, but it could still provide diverse information for this research. The respondents were chosen based on the required criteria by the teachers who taught the D\&T subject in 2017 and had academic qualifications at postgraduate level in the field of secondary school education. The sample used in the research is a total of 100 teachers, which represents the entire population. Respondents chosen for this study are those who are directly involved in the implementation of D\&T subject. The interviews were also conducted with the specialists in the selected D\&T field to further enhance the findings of this study.

Table 3.2: The Number of schools and the number of teachers, according to the selected zone.

\begin{tabular}{lcc}
\hline Zone & Number of High Schools & Number of Teachers \\
\hline East & 385 & 1618 \\
\hline Middle & 312 & 2008 \\
\hline South & 377 & 1616 \\
\hline North & 465 & 1180 \\
\hline Total & 1539 & 6422 \\
\hline
\end{tabular}

(Source: Bahagian Pendidikan Malaysia, 2018)

The instrument used in this research to collect the required data is a set of questionnaires. The questionnaire was constructed using three approaches in which the first approach is the subjective or open-ended question, where this type of item was used to obtain feedback and open text format from respondents (Ghazali \& Sufean, 2016; David Pratt, 1980), the second approach used 
is the Likert scale survey questions, and lastly the Dichotomy Test items. The questionnaire consists of four parts. Part A focuses on the respondents' background or demographic information. While Part $B$ contained open-ended questions that identify the challenges in the implementation of D\&T subject. Part $C$ concerns with the mastery level of D\&T content and Part $D$ pertain to the requirements and agreements for the development of measurement instruments. For Part $C$ and $D$, both parts contained a set of multiple-choice questions where respondents are given several choices of answer stating the degree of agreements, which is in the form of 3-point Likert scale and both sections also ended with an open-ended question. These open-ended questions will give the respondents an opportunity to express their opinion or convey ideas that they think is necessary and important aside from the items listed in the questionnaire.

\section{Findings}

The data that has been analyzed is then presented in the form of tables according to the items that have been constructed to answer each objective of the study.

Objective 1: Identifying the challenges faced by teachers who teach Design and Technology subject in high school.

Table 1: The challenges faced by teachers that teach D\&T subject in high school.

\begin{tabular}{lc}
\hline \multicolumn{1}{c}{ Challenges } & Percentage (\%) \\
\hline Mastery of knowledge among teachers is low & 85 \\
\hline The skills mastery among teachers is low & 75 \\
\hline The ability to grasp the attitude and the values among teachers is low & 55 \\
\hline Students' competency and proficiency are low & 81 \\
\hline Lack of experience in Design and Technology & 90 \\
\hline Non-option teachers & 90 \\
\hline Practical activities require a lot of cost & 60 \\
\hline Unfavorable workshop equipment & 70 \\
\hline Lack of guidance & 75 \\
\hline Lack of related courses being offered & 75 \\
\hline The content of the textbook does not align with the DSKP & 30 \\
\hline There are no focuses in the learning content & 45 \\
\hline Not very clear with the format of the assessment & 87 \\
\hline
\end{tabular}

Table 1 above shows the data obtained for the challenges faced by teachers who teach Design and Technology subject in high school. From the survey conducted, many respondents had claimed that their level of competency is at a low level. $85 \%$ of respondents stated that their knowledge regarding D\&T content is at a low level. Meanwhile, $75 \%$ of respondents also stated that their skills in Design and Technology is also at a low level and $55 \%$ of them said they are still inadequate in term of attitude and values concerning Design and Technology. In addition, $81 \%$ of respondents stated that the competency and proficiency of the students are at a low level. $90 \%$ of respondents expressed the biggest challenge that they have to face is the lack of experience and teaching a non-option subject, which in this case to teach D\&T subject. The respondents also face challenges such as to conduct practical activities will cost a lot of money and unfavorable equipment in the workshop. These 
INTERNATIONAL JOURNAL OF ACADEMIC RESEARCH IN BUSINESS AND SOCIAL SCIENCES Vol. 9, No. 6, June, 2019, E-ISSN: 2222-6990 (C) 2019 HRMARS

challenges recorded of more than $60 \%$ of the respondents. $75 \%$ of the respondents found themselves lacking in receiving guidance and courses that can help them to improve their understanding. Only a small number of respondents expressed that they are having issues with the content of the textbook which does not align with DSKP and that there are no focuses on the learning content. And lastly, $87 \%$ of the respondents claimed that they are not very clear or unsure regarding the format of the assessment.

Objective 2: Identifying the level of content mastery among teachers who teach Design and Technology subject in high school

Table 2: Mastery level of content knowledge among teachers that teach D\&T subject in high school.

\begin{tabular}{|c|c|c|c|c|}
\hline Construct & Sub-construct & $\% M$ & \%Ts & \%T \\
\hline \multirow{8}{*}{$\begin{array}{l}\text { Knowledge of } \\
\text { the content }\end{array}$} & Introduction to Design and Technology & 25 & 33 & 42 \\
\hline & Introduction of Design Project Management & 30 & 38 & 32 \\
\hline & Design process & 26 & 37 & 47 \\
\hline & Sketches & 22 & 47 & 31 \\
\hline & $\begin{array}{l}\text { Apply Technology } \\
\text { Fertigation Design } \\
\text { Fashion Design } \\
\text { Design Manufacturing Technology } \\
\text { Mechanical Design } \\
\text { Electrical Design } \\
\text { Aquaponic System Design } \\
\text { Food Design } \\
\text { Electromechanical Design }\end{array}$ & 26 & 32 & 42 \\
\hline & Creative problem solving & 20 & 36 & 44 \\
\hline & Product development & 27 & 39 & 44 \\
\hline & The role of design in business & 22 & 37 & 41 \\
\hline
\end{tabular}

Key:

$M=$ Master the knowledge and can fully understand

$\mathrm{Ts}=$ Not fully mastering the knowledge and comprehension

$\mathrm{T}=$ Not able to understand and grasp the knowledge

Table 2 shows the mastery level of D\&T content among teachers in high school. The findings show that the level of content mastery among teachers is at a low level. There are less than $30 \%$ of the respondents who could master the knowledge and can fully understand the subject. Meanwhile, less than $40 \%$ of the respondents can understand, but not fully grasp or mastering the subject and less than $50 \%$ of the respondents cannot mastered the content.

Objective 3: To observe the needs for the development of the measurement instrument to measure the content mastery among teachers who teach D\&T subject in high school. 
INTERNATIONAL JOURNAL OF ACADEMIC RESEARCH IN BUSINESS AND SOCIAL SCIENCES Vol. 9, No. 6, June, 2019, E-ISSN: 2222-6990 @ 2019 HRMARS

Table 3: The need for the development of a measurement instrument to measure the content mastery among teachers who teach D\&T subject in high school.

\begin{tabular}{lccc}
\hline \multicolumn{1}{c}{ Item } & Available & $\begin{array}{c}\text { Not } \\
\text { available }\end{array}$ \\
\hline $\begin{array}{l}\text { In your opinion, is there an instrument available for teachers } \\
\text { which measured their level of mastering on knowledge } \\
\text { competency in regards to the content of D\&T subject? }\end{array}$ & $2 \%$ & & \\
\hline & $\% \mathrm{~S}$ & $\% \mathrm{TS}$ & $\% \mathrm{~T}$ \\
\hline $\begin{array}{l}\text { In your opinion, is it necessary to find a solution to the } \\
\text { problem faced by teachers in mastering the content of D\&T? }\end{array}$ & 85 & 12 & 3 \\
\hline $\begin{array}{l}\text { In your opinion, is it necessary to develop a competence } \\
\text { measurement instrument that can measure the proficiency } \\
\text { level among teachers concerning their mastery of D\&T } \\
\text { content knowledge? }\end{array}$ & & & \\
\hline
\end{tabular}

Key:

$S=$ Agreed

Ts = Not fully agreed

$\mathrm{T}=$ Not agreed

Table 3 shows the findings of the need to develop a competence measurement instrument that can measure the proficiency level of D\&T content knowledge among teachers in high school. A total of $98 \%$ of the respondents stated that there was no instrument available for teachers, that can measure the proficiency of their content knowledge in Design and Technology subject. In the meantime, $83 \%$ of the respondents agreed to the need to establish a competence measurement instrument that can measure the proficiency level of Design and Technology content knowledge among teachers.

\section{Discussion}

The requirements analysis research requires the researcher to gather information regarding the context and the situation of the research from teachers who are also the implementers of D\&T subject in high school. In regards to the context of this study, the researcher collects information regarding the problems faced by the teachers, the existing proficiency or mastery level, and the needs to develop a measurement instrument to measure the content knowledge among teachers. This information obtained can help the researcher to produce a valid and reliable instrument and can help solve the existing problems. The results of the requirement analysis found that the measurement instrument to measure the competency and proficiency level of Design and Technology content knowledge among teachers should be developed in order to help teachers identify their level of proficiency or mastery in regards to D\&T content knowledge with more details. The findings also show many respondents claimed that there is still no competency measurement instrument available for teachers to measure their mastery level in Design and Technology content knowledge. Thus, all teachers had agreed that it is necessary to establish a measurement instrument in order to find a 
solution to the existing problem in mastering D\&T content knowledge. Due to this, the survey received positive feedback and strong agreement from teachers, they strongly believe in the need to establish a measurement instrument that can measure the mastery level of D\&T content knowledge among teachers who teach the subject.

Therefore, to teach a subject, teachers need to master the content knowledge and always be aware of recent knowledge or information (Koehler, Greenhalgh, Rosenberg \& Keenan, 2017; Cherner \& Smith; 2016). From the findings, it also shows that when in the classroom, teachers need to have all around knowledge regarding education, which includes theories, concepts, and principle, and at the same time also possess and able to grasp the content knowledge of a particular subject. In accordance with Malaysian education, content knowledge is the learning content contained in the Secondary School Standard Curriculum. Based on the findings in a study conducted by Tchoshanov, Cruz, Huereca, et al., (2017), it shows that teachers' content knowledge plays an important role in student performance in middle schools. In addition, according to the study conducted by Jain, Mariani, Abdul, and Nazri, 2018; Aguinaldo, 2017; Atasoy \& Aygun, 2016 found that content knowledge does influence the way teachers plan and teach the subject. Meanwhile, Shulman (1986) in a case study entitled Knowledge Growth In teaching found that 90 to $95 \%$ of the findings showed that teachers should master the basis of general knowledge. This means that the mastery of content knowledge and the attitude of teachers during the teaching process in the classroom is influenced by the knowledge that they have in themselves (Atasoy \& Aygun (2016), Cherner \& Smith (2016). In the context of education, if teachers can master and possess the content knowledge, the implementation of teaching and learning process can be conducted as what has been planned beforehand, but otherwise, teachers will face issues and constraints in order to implement teaching and learning process in the classroom.

The findings of this requirement analysis will be useful for other researchers as a guide for them to design and develop measurement instruments in the next phase of instrumentation development. Based on the findings obtained, there is potential for the measurement instrument to measure the mastery level of content knowledge for D\&T teaching and learning to be developed for the use of teachers in high school.

\section{Conclusion}

In line with the changes in the education policy, the proficiency of teachers' content knowledge needs to be enhanced for them to carry out their duties professionally and competently. Hence, the development of an instrument to measure the mastery level of content knowledge among D\&T teachers' is significant. The epistemology of knowledge focuses on what we know and how we come to know it. It is one of the philosophical branches that considers the nature and scope of knowledge, along with the assumptions and general basis of reliability when it's in concern with the knowledge demands. Past studies have proven the needs for teachers to have content knowledge, which will help them to become more effective in teaching. Knowledge and the proficiency in content knowledge will allow teachers to understand certain issues such as what makes learning a particular subject or topic easy or hard for the students, about conception, pre-conception, and misconceptions 
that students have. According to the findings obtained regarding the teachers' comprehension of content knowledge, it is clearly indicate that the effectiveness of teaching and learning depends largely on the ability of the teachers to apply critically real-life situations in the classroom in order to solve a problem or issues related to education. The results of this study can explain the strengths and weakness of teachers' knowledge, skills, and value, where it can be used as a guide in the future to plan for professional development programs.

\section{Corresponding Author}

\section{Owi Kim Huei}

Department of Engineering Technology, Faculty of Technical and Vocational

Universiti Pendidikan Sultan Idris 35900 Tanjong Malim, Perak.

Email: owikimhuei@yahoo.com

\section{References}

Atasoy, E., U. N., \& Aygun, B. (2016). Technological pedagogical content knowledge of prospective mathematics teachers regarding evaluation and assessment. World Journal on Educational Technology, 8(1), 18-24. doi:10.18844/wjet.v8i1.496.

Aguinaldo, B. E. (2017). Developing and applying technological pedagogical and content knowledge (TPACK) for a blended learning environment: A rural higher education experience in the Philippines. Countryside Development Research Journal, 4(1), 27-35.

Branch, R. M. (2009). Instructional design: The ADDIE approach. New York, NY: Springer

Cherner, T., \& Smith, D. (2016). Reconceptualizing TPACK to meet the needs of twenty-firstcentury education. The New Educator. Advance online publication. doi:10.1080/1547688x.2015.1063744.

DeWitt, D. (2010). Development of collaborative mLearning module on nutrition for Form Two students.Tesis PhD. Fakulti Pendidikan, Universiti Malaya.

Gagne, M. R., Wager, W. W., Golas, K. C., \& Keller, J. M. (2005). Principles of instructional design (5th ed.). Belmont, CA: Wadsworth.

Koehler, M., Greenhalgh, S., Rosenberg, J., \& Keenan, S. (2017). What the tech is going on with teachers? Digital teaching portfolios? Using the TPACK framework to analyze teacher? Technological understanding. Journal of Technology and Teacher Education, 25(1), 31- 59.

Rahmat, R. (2013). Pembangunan dan penilaian pakej pembelajaranmudah alih Komsas dalam bahasa Inggeris Tingkatan Empat. Tesis PhD, Fakulti Pendidikan, Universiti Kebangsaan Malaysia.

Richey, R. C., \& Klein, J. D. (2007). Design and developmental research.New York, NY: Routledge.

Saedah Siraj, Norlidah Alias, Dorothy DeWitt, \& Zaharah Hussin. (2013). Design and developmental research: Emergent trends in educational research.Kuala Lumpur: Pearson Malaysia.

Surat Pekeliling Ikhtisas Kementerian Pendidikan Malaysia Bilangan 9. (2016).

Shulman, L. S. (1986). Those who understand teach: Knowledge growth in teaching. Educational Researcher, 15(2), 4- 14. 
INTERNATIONAL JOURNAL OF ACADEMIC RESEARCH IN BUSINESS AND SOCIAL SCIENCES

Vol. 9, No. 6, June, 2019, E-ISSN: 2222-6990 @ 2019 HRMARS

Tchoshanov, M., Cruz, M., Huereca, K., Shakirova, K., Shakiro, L., \& Ibragimova, L. (2017). Examination of Lower Secondary Mathematics Teachers' Content Knowledge and Its Connection to Students' Performance. International Journal of Science and Mathematics Education, 15(4), 683-702. Doi: 10.1007/s10763-015-9703-9. 